Syntax Literate: Jurnal Ilmiah Indonesia p-ISSN: 2541-0849

e-ISSN: 2548-1398

Vol. 5, No. 8, Agustus 2020

\title{
EVALUASI PROFIL PENGOBATAN DAN OUTCOME KLINIS PENGGUNAAN INSULIN ANALOG PADA PASIEN BPJS DM TIPE 2 DI RSUP PERSAHABATAN JAKARTA
}

\section{Rosdaniati, Yusi Anggriani, Hesty Utami R. dan Tri Kusumaeni}

Magister Farmasi Universitas Pancasila Jakarta, Indonesia

Email: rosdaniati06@gmail.com,yusi1777@yahoo.com,

h.ramadaniati@graduate.curtin.edu.audan trikusumaeni@yahoo.com

\section{Abstract}

Insulin is used to lower blood glucose and HbAlC levels and can reduce microvascular complications. The purpose of this study was to determine the profile of treatment, the factors that influence the choice of insulin therapy and to determine the differences in clinical outcomes of patients with type 2 diabetes mellitus who use insulin at the Friendship Hospital. This study is a retrospective study, which was conducted using a longitudinal time series. The population was BPJS type 2 DM patients at the Friendship Hospital for the period January 2017December 2018 totalling 1,100 patients. A sample of 285 was taken using the Krecjie Morgan formula. Data comes from medical records in the Hospital Pharmacy Installation using a questionnaire and processed and analyzed with SPSS version 23. The most commonly prescribed oral DM drug is a sulfonylurea. Non-DM drugs that are often prescribed are heart drugs. The insulin that is often used by type is Humalog insulin, the brand is Humalog Mix and based on its work is intermediate-acting analogue insulin. Based on clinical outcomes, clinical outcomes of GDP, GDPP and $\mathrm{HbAlC}$ in patients aged $\leq 60$ years or $>60$ years are generally uncontrolled/poor. Based on the results of the Kruskal Walls test, in the GDP outcome, there was a significant difference between insulin groups (at least one pair of groups were significantly different) on the GDP outcome. In the GDPP and HbAlC outcomes, there was no significant difference between the insulin groups on the GDPP and HbAlC outcomes. Based on the results of the Mann Whitney test, with 28 groups of insulin partners, the clinical outcome value of GDP was significantly different, namely the comparison of therapy between fast-acting insulin and intermediate-acting insulin analogues, as well as between fast-acting insulin and insulin combinations, both combinations using 2 types of insulin. analogues, or a combination of analogue insulin and ADO. In the clinical outcome test, GDPP was significantly different in the comparison of therapy between fastacting insulin and long-acting insulin with a combination of intermediate-acting insulin and ADO. The HbAlc results showed no difference in the therapeutic use of various types of insulin.

Keywords: Insulin; DM drugs; non DM drugs; Diabetes Mellitus 


\begin{abstract}
Abstrak
Insulin digunakan untuk menurunkan glukosa darah dan kadar HbA1C serta dapat mengurangi komplikasi mikrovaskular. Tujuan penelitian ini adalah untuk mengetahui profil pengobatan, faktor-faktor yang mempengaruhi dalam pemilihan terapi insulin dan untuk mengetahui perbedaan outcome klinis pasien diabetes melitus tipe 2 yang menggunakan insulin di RSUP Persahabatan. Penelitian ini merupakan penelitian retrospektif, yang dilakukan secara longitudinal time series. Populasi adalah pasien BPJS DM tipe 2 RSUP Persahabatan periode Januari 2017Desember 2018 sejumlah 1.100 pasien. Sampel sebanyak 285 diambil dengan rumus Krecjie Morgan. Data berasal dari rekam medis di Instalasi Farmasi Rumah Sakit menggunakan formulir isian dan kuesioner dan diolah serta dianalisa dengan SPSS versi 23. Obat DM oral yang banyak diresepkan adalah Sulfonilurea. Obat non DM yang sering diresepkan adalah obat jantung. Insulin yang sering digunakan berdasarkan jenis adalah insulin Humalog, merk adalah Humalog Mix dan berdasarkan kerja adalah Insulin analog intermediate acting. Berdasarkan outcome klinik, outcome klinik GDP, GDPP dan HbA1C pada pasien usia $\leq 60$ tahun atau $>60$ tahun secara umum termasuk tidak terkendali/buruk. Berdasarkan hasil uji Kruskall Walls, pada outcome GDP ada perbedaan yang signifikan diantara golongan insulin (minimal ada satu pasang golongan yang berbeda nyata) terhadap outcome GDP. Pada outcome GDPP dan HbA1C tidak ada perbedaan yang signifikan diantara golongan insulin terhadap outcome GDPP dan HbA1C. Berdasarkan hasil uji Mann Whitney, dengan 28 kelompok pasangan insulin, diperoleh hasil nilai outcome klinik GDP berbeda nyata yaitu pada perbandingan terapi antara insulin fast acting dengan insulin analog intermediate acting, begitupun antara insulin fast acting dan kombinasi insulin, baik kombinasi yang menggunakan 2 macam insulin analog, maupun kombinasi antara insulin analog dan ADO. Pada uji nilai outcome klinik GDPP berbeda nyata pada perbandingan terapi antara insulin fast acting maupun insulin long acting dengan kombinasi insulin intermediate acting dan ADO. Pada hasil HbA1c menunjukkan tidak ada perbedaan penggunaan terapi berbagai jenis insulin.
\end{abstract}

Kata kunci : Insulin, obat DM; obat non DM; Diabetes Mellitus

\title{
Pendahuluan
}

Indonesia mengalami pergeseran pola penyakit dari penyakit menular menjadi penyakit tidak menular. Hal ini disebabkan oleh meningkatnya status sosial dan ekonomi, pelayanan kesehatan masyarakat, perubahan gaya hidup, bertambahnya umur harapan hidup. Salah satu jenis penyakit tidak menular yang selalu mengalami peningkatan dari tahun ke tahun adalah diabetes mellitus (Hastuti RT.,2008, Andayani TM.,2006). Dari pengukuran yang dilakukan Riset kesehatan dasar (RIKESDAS) tahun 2018, rata-rata pasien yang terdiagnosa DM pada semua umur sebesar 1,5\%(Widodo C,dkk,2016, Riskesdas,2018).

Diabetes mellitus (DM) merupakan masalah kesehatan yang dapat mengakibatkan penurunan kualitas sumber daya manusia dan berdampak pada produktivitas. Berdasarkan penyebabnya penyakit kronis ini dibagi menjadi dua tipe, yaitu DM tipe 1 dan DM tipe 2. Diabetes tipe 2 adalah bentuk diabetes yang paling umum dan paling 
banyak prevalensinya. Hampir 200 juta orang dengan diabetes tidak terdiagnosis. Oleh karena itu, lebih berisiko mengembangkan komplikasi, yang termasuk gagal ginjal, kebutaan, amputasi, penyakit jantung dan stroke, sehingga berpotensi meningkatkan biaya perawatan dan menurunkan kualitas hidup (Baroroh F,dkk,2016, IDF,2017).

Untuk meningkatkan kualitas hidup pasien DM, dilakukan terapi non farmakologi dan farmakologi. Terapi farmakologi yang diberikan untuk pengobatan DM tipe 2 terdiri dari obat oral dan bentuk suntikan. Obat antihiperglikemik oral antara lain: pemicu sekresi insulin (sulfonilurea, glinid), peningkat sensitivitas terhadap insulin (meformin, TZD), penghambat absorpsi glukosa di saluran pencernaan (penghambat alfa glukosidase, penghambat DPP IV, penghambat SGLT-2). Obat antihiperglikemik suntik antara lain insulin, agonis GLP-1, dan kombinasi insulin dan agonis GLP-1 (Ndraha S.,2014) .

Insulin digunakan untuk pengobatan DM tipe 1 dan DM tipe 2, pada pasien DM tipe 2 terapi insulin digunakan untuk menurunkan glukosa darah dan bisa digunakan untuk menurunkan kadar $\mathrm{HbA1C}$ sesuai target yang diinginkan, serta dapat mengurangi komplikasi mikrovaskular. Saat ini di Indonesia terdapat beberapa jenis insulin, Berdasarkan onset kerjanya, insulin dapat dibedakan menjadi empat tipe, yaitu insulin kerja cepat (rapid acting), insulin kerja pendek (short acting), insulin kerja menengah (intermediate acting) dan insulin kerja panjang (long acting) (Rosdiana D.,2014) .

Dari uraian tersebut, dalam terapi pasien DM tipe 2, jenis insulin yang digunakan akan berpengaruh terhadap biaya dan hasil terapi. Salah satu tolak ukur dalam pencapaian terapi adalah outcome klinis, yaitu gambaran suatu keberhasilan terapi yang dapat dilihat pada pasien setelah mendapatkan perawatan atau pengobatan. Menurut Food and Drug Administration (FDA), penilaian Outcome klinis dilakukan berdasarkan gejala, kondisi mental, dan pengaruh penyakit terhadap aktivitas pasien (FDA, 2013).

Rumah Sakit Umum Pusat Persahabatan (disingkat RSUP Persahabatan) merupakan rumah sakit tipe A yang terletak di Jakarta Timur dengan jumlah pasien DM di Rumah sakit ini cukup tinggi, sehingga perlu dilakukan penelitian tentang Analisis Penggunaan Insulin Pada Pasien Umum dan BPJS DM Tipe 2 di RSUP Persahabatan. Tujuan dilakukan penelitian ini adalah Untuk mengetahui penggunaan insulin analog pada pasien DM type 2, untuk mengetahui faktor-faktor yang mempengaruhi dalam pemilihan terapi insulin dan untuk mengetahui perbedaan outcome klinis pasien diabetes melitus tipe 2 yang menggunakan insulin di RSUP Persahabatan.

\section{Metode Penelitian}

Penelitian yang dilaksanakan merupakan penelitian retrospektif, yang dilakukan secara longitudinal time series yaitu pengumpulan data yang memerlukan lebih dari satu tahap pengumpulan data pada saat yang berbeda dan data penelitian berupa rentetan waktu. Pengambilan data dari rekam medis yang berasal dari Instalasi Farmasi Rumah Sakit. Populasi dalam penelitian ini merupakan pasien umum dan BPJS DM tipe 2 RSUP Persahabatan periode Januari 2016-Desember 2017 berjumlah 1.100 pasien. Pengambilan sampel dilakukan pada pasien yang memenuhi kriteria inklusi 
menggunakan rumus Krecjie Morgan dan diperoleh sampel sebanyak 285 pasien. Data yang dikumpulkan berupa data demografi pasien, profil pengobatan, dan outcome klinis dengan menggunakan formulir yang diadopsi dari CRF Kementerian Kesehatan Direktorat Pelayanan Kefarmasian dan lembar kuesioner untuk wawancara para dokter spesialis penyakit dalam. Data kemudian diolah dan dianalisa secara deskriptif dan statistic dengan bantuan SPSS versi 23. Penelitian ini juga merupakan penelitian kualitatif yang dilakukan dengan mewawancarai dokter spesialis penyakit dalam yang meresepkan insulin.

\section{Hasil dan Pembahasan}

1. Karakteristik Pasien

Data demografi pasien DM Tipe 2 rawat jalan pengguna insulin, menunjukkan bahwa berdasarkan jenis kelamin terbanyak adalah berjenis kelamin perempuan yaitu sebanyak 52,63\% (2017) dan 50,40\% (2018). Hasil penelitian ini sesuai dengan hasil Riset Kesehatan Dasar yang menyebutkan bahwa jumlah penderita Diabetes terbanyak diderita oleh perempuan (Riskesdas,2013). Juga sejalan dengan penelitian yang dilakukan Inayah, dkk bahwa sampel pasien DM type 2 di Rumah Sakit X Pekan Baru sebagian besar adalah perempuan yaitu 55,6\% dan laki-laki sebanyak 44,4\% (Sari, Inayah, \& Hamidy, 2016). Penelitian berikutnya yaitu Ratnasari dan Bargah bahwa jenis kelamin sampel pasien DM type 2 dari RSU Negara sebagiaan besar perempuan $(50,8 \%)$ (Ratnasari \& Bhargah, 2018). Perbedaan jenis kelamin dalam distribusi lemak tubuh berkaitan erat dengan resistensi insulin, hal ini disebabkan karena perempuan memiliki lebih banyak lemak subkutaneus yang berhubungan dengan peningkatan sensitifitas terhadap insulin. (Eliza B Geer WS.,2010) Sedangkan bentuk anatomis, fisiologis dan sistem hormonal yang berbeda juga dapat menimbulkan terjadinya perbedaan insiden penyakit. Selain itu dapat disebabkan oleh perbedaan jenis pekerjaan, kebiasaan dan pola makan. (Noor N.,2008).

Berdasarkan usia pasien, yang paling banyak pada usia 55-64 tahun, sebesar $31,10 \%$ (2017) dan 34,40\% (2018), hal ini sesuai dengan hasil dari Riskesdas tahun 2018 dimana jumlah penderita DM terbanyak pada usia 55-64 tahun (Riskesdas,2013). Sejalan juga dengan penelitian Ayu nindi dkk yang menyebutkan bahwa jumlah kasus terbanyak penderita DM tipe 2 pada usia 55-64 tahun. dalam hal ini tidak hanya faktor fisiologis saja yang mempengaruhi kelompok usia tua mengidap penyakit DM tipe 2, faktor lingkungan juga mempengaruhi kejadian DM tipe 2 (Kistianita AN,Gayatri RW.,2018) Hal ini didukung juga oleh penelitian yang dilakukan oleh Emma \& Idris bahwa serangan dari DM tipe 2 pada orang dewasa lebih di-karenakan individu tersebut obesitas, mempunyai riwayat keturunan DM tipe 2, pola hidup yang tidak seha. (Emma,Wilmot \& Idris I.,2014).

Pada variabel diagnosa pasin DM tipe 2 diperoleh hasil yang paling banyak terjadi adalah dengan kode ICD-10 E11.8 (Non-Insulin-Dependent Diabetes Mellitus with Unspecified Complications), dengan kejadian komplikasi terbanyak pada 
neuropati DM, yaitu sebesar 4,78 \% pada tahun 2017 dan sebanyak 2,4\% pada tahun 2018. Sedangkan untuk penyakit penyerta yang dialami oleh pasien DM pada penelitian ini adalah hipertensi, yaitu sebesar $13.9 \%$ pada tahun 2017 dan $16.0 \%$ pada tahun 2018. Hasil penelitian sejalan dengan penelitian Stanifer et.al. dimana ada keterkaitan antara riwayat hipertensi dengan neuropati diabetic. Hipertensi dapat menyebabkan penebalan pembuluh darah arteri menyebabkan diameter pembuluh darah menyempit. Penyempitan pembuluh darah akan mempengaruhi pengangkutan metabolisme dalam darah, sehingga kadar glukosa dalam darah akan terganggu (Stanifer, J.W.,et.all,2016).

Dari karakteristik pendidikan pasien, yang paling banyak adalah pendidikan SMA yaitu sebesar 77,99 \% (2017) dan 77,60\% (2018), dan pekerjan pasien umumnya swasta. Pendidikan merupakan dasar utama keberhasilan pengobatan, sehingga kemampuan serta pemahaman tentang managemen DM dinilai rendah. (Cai Le,,et.all.,2011) Sedangkan untuk pasien DM pekerja memiliki jam kerja tinggi dengan jadwal yang tidak teratur sehingga menjadi faktor penting dalam meningkatnya penyakit DM. Selain itu lingkungan kerja yang kurang sehat dalam hal ini dapat mengakibatkan terganggunya jadwal makan dan tidur sehingga akan mengakibatkan kenaikan berat badan dan beresiko besar terkena DM. (Frank H.,2008).

Jumlah kunjungan terbanyak pasien DM type 2 adalah 3-5 kali kunjungan yaitu pada tahun 2017 sebesar 43,54 \% dan tahun 2018 sebesar 35,20\%, jumlah kunjungan 9-11 kali pada tahun 2017 sebesar 36,84\% sedangkan tahun 2018 sebesar 32,00\%. Dilihat dari banyaknya jumlah kunjungan mengindikasikan bahwa kondisi pasien DM belum mengalami kestabilan, sehingga diperlukan kontrol setiap bulannya, menurut penelitian yang dilakukan oleh Valentina dkk, bahwa banyak faktor yang mempengaruhi kestabilan kondisi penyakit DM, yaitu kesibukan juga dapat mengakibatkan pasien lupa minum obat. Selain itu, pasien mengaku lupa dikarenakan bepergian dan lupa membawa obat, atau kondisi dimana pasien merasa sehat dan saat merasa tidak ada keluhan (Srikart,Ika VM,dkk.,2011).

Sesuai data yang diambil dari Rekam medik pasien penggunaan insulin di RSUP Persahabatan terbanyak ada pada golongan insulin intermediate acting (insulin analog premix) dari tahun 2017 dan 2018. Penggunaan selanjutnya disusul oleh insulin kerja panjang (insulin analog long acting) dan insulin kerja cepat (insulin analog fast acting). Hasil ini berbeda dengan penelitian Luh Putu,dkk bahwa insulin yang paling banyak digunakan pada pasien DM type 2 di Kota Denparar adalah golongan rapid acting (Riskesdas,2018). Berbeda pula penelitian Inayah,dkk yang banyak digunakan pada pasien di RS X Pekan Baru adalah insulin golongan Short Acting (Hastuti RT.,2008). Namun sejalan dengan penelitian Vitriana G.,dkk bahwa rata-rata dosis insulin yang diguanakn paing banyak adalah golongan premixed insulin (Ratnasari \& Bhargah, 2018).

Menurut American Diabetes Association (ADA) pada tahun 2018, pertimbangkan untuk memulai terapi insulin (dengan atau tanpa obat tambahan) pada 
pasien DM tipe 2 baru terdiagnosis yang disertai gejala dan/atau memiliki kadar $\mathrm{HbAlc} \geq 10 \%(86 \mathrm{mmol} / \mathrm{mol})$ dan/atau kadar gula darah $\geq 300 \mathrm{mg} / \mathrm{dL}(16,7 \mathrm{mmol} / \mathrm{L})$ atau pada pasien yang sudah terdiagnosis DM tipe 2, bila target HbA1c tidak tercapai dalam 3 bulan penggunaan 3 obat antihiperglikemik oral. Sasaran pertama terapi hiperglikemia adalah mengendalikan glukosa darah basal (puasa, sebelum makan). Insulin yang dipergunakan untuk mencapai sasaran glukosa darah basal adalah insulin basal (insulin kerja sedang atau panjang). Insulin basal biasanya disuntikkan di malam hari, dikombinasikan dengan metformin atau terkadang agen non insulin lainnya (Ratnasari \& Bhargah, 2018)

2. Evaluasi Profil Pasien

a) Jumlah Kunjungan

Berdasarkan hasil jumlah kunjungan pasien diabetes melitus tipe 2 pengguna insulin pada tabel 1, persentase kunjungan tertinggi yakni pada tahun 2017 sebanyak 3-5 kali kunjungan sebesar 54,55 \% dengan total pasien 114 orang. Pada tahun 2018 terbanyak kunjungan 3-5 kali juga dengan total pasien 64 orang atau $51,20 \%$.

Tabel 1 Jumlah Kunjungan Rawat Jalan Pasien DM tipe 2 Pengguna Insulin Periode 2017-2018 di RSUP Persahabatan

\begin{tabular}{lcccc}
\hline \multirow{2}{*}{ Variabel } & \multicolumn{2}{c}{ Tahun 2017 } & \multicolumn{2}{c}{ Tahun 2018 } \\
\cline { 2 - 5 } & Jumlah & \% & Jumlah & \% \\
\hline Kunjungan <3 kali & 7 & 3.35 & 21 & 16.80 \\
\hline Kunjungan 3-5 kali & 114 & 54.55 & 64 & 51.20 \\
\hline Kunjungan 6-8 kali & 48 & 22.97 & 28 & 22.40 \\
\hline Kunjungan 9-11 kali & 28 & 13.88 & 12 & 9.60 \\
\hline Kunjungan $\geq 12$ kali & 12 & 5.26 & 0 & 0.00 \\
\hline
\end{tabular}

Hal ini menunjukkan bahwa masih belum stabilnya kondisi pasien DM yang melakukan rawat jalan di RSUP Persahabatan, karena masih tingginya jumlah kunjungan yang terjadi. Pasien yang melakukan kunjungan kurang dari 3 kali selama tahun 2017 dapat masuk kedalam kriteria inklusi dan tetap dijadikan sampel pada penelitian ini, karena pasien tersebut melakukan kunjungan juga di tahun 2018. Dari jumlah kunjungan yang masih tinggi, mengindikasikan bahwa pasien DM masih rutin dalam melakukan kontrol penyakitnya. Kondisi penyakit DM nya pun belum stabil, sehingga diperlukan pemeriksaan rutin tiap bulan oleh dokter penyakit dalam. Hasil ini sejalan dengan penelitian Vitriana G.,dkk bahwa rata-rata pasien menderita DM type2 adalah 6,3 $\pm 4,36$ tahun (Ratnasari \& Bhargah, 2018), artinya bahwa semakin lama seorang pasien menderita DM typ2, maka kunjungannya semakin meningkat. Apabila kondisi gula darah pasien DM ini sudah stabil maka bisa dirujuk ke FKTP (Fasilitas Kesehatan Tingkat Pertama) untuk melanjutkan pengobatannya. (Dirut BPJS Kesehatan). 
b) Hasil Pemeriksaan Laboratorium

1) Hasil pemeriksaan laboratorium berdasarkan psien yang menggunakan insulin

Setiap kali melakukan kunjungan rawat jalan, pasien DM dilakukan pemeriksaan GDP (Gula darah puasa) dan GDPP (Gula darah 2 jam setelah makan) serta pemeriksaan HbA1c meskipun tidak rutin diperiksa 3 bulan sekali. Gambar 1 dan 2 menunjukan hasil rata-rata dan rentang pemeriksaan GDP,GDPP dan HbA1c penggunaan insulin pasien DM tipe 2 periode tahun 2017-2018. Nilai HbA1c rata-rata yang diperoleh pada penelitian ini diatas 9\%, maka pasien memerlukan terapi insulin untuk pengobatan DM nya. Hal ini sesuai dengan PERKENI tahun 2015 bahwa untuk pasien DM tipe 2 dengan HbA1c > 9, maka diperlukan terapi insulin (Perkumpuan Endrokinologi Indonesia, 2015). Untuk pasien yang kadar HbA1c nya $<9$ merupakan pasien yang sudah lama berobat atau pasien yang melakukan kontrol setelah rawat inap. Rata-rata kadar GDP yang paling tinggi 187,62 $\mathrm{mg} / \mathrm{dL}$ sedangkan rata-rata GDP yang paling rendah $138,53 \mathrm{mg} / \mathrm{dl}$. Hal ini masih menunjukan tingginya kadar gula darah pasien, sehingga diperlukannya insulin sebagai terapi pengobatan. Kadar rata-rata GDPP yang paling tinggi 290,39 mg/dl sedangkan rata-rata GDPP yang paling rendah $211,88 \mathrm{mg} / \mathrm{dl}$, hal ini menunjukkan bahwa kadar gula darah pasien 2 jam sesudah makan masih belum stabil, sehingga masih diperlukan kontrol rutin setiap bulannya ke fasilitas kesehatan tingkat lanjut. Hasil ini sejalan dengan penelitian Vitriana G., dkk bahwa kadar GDP dan GDPP pasien DM type 2 masih dalam katagori buruk (GDP 72\% dan GDPP 75\%). Hal ini berhubungan dengan adanya beberapa faktor yang mempengaruhi penggunaan insulin pada pasien diantaranya, tingkat pendidikan, tingkat pengetahuan terhadap penyakit, kepatuhan berobat, dan pengaturan dosis insulin yang belum maksimal. Salah satu penyebab utama pengaturan dosis yang tidak optimal dikarenakan adanya komplikasi akut berupa hipoglikemi yang dapat menyebabkan kematian (Ratnasari \& Bhargah, 2018).

2) Hasil pemeriksaan laboratorium berdasarkan jenis insulin

Kadar GDP dan GDPP serta hasil perhitungan HbA1C pasien DM type 2 dikatagorikan menurut jenis insulin yang digunakan disajikan pada gambar 3 dan gambar 4. 
Rosdaniati, Yusi Anggriani, Hesty Utami R. dan Tri Kusumaeni

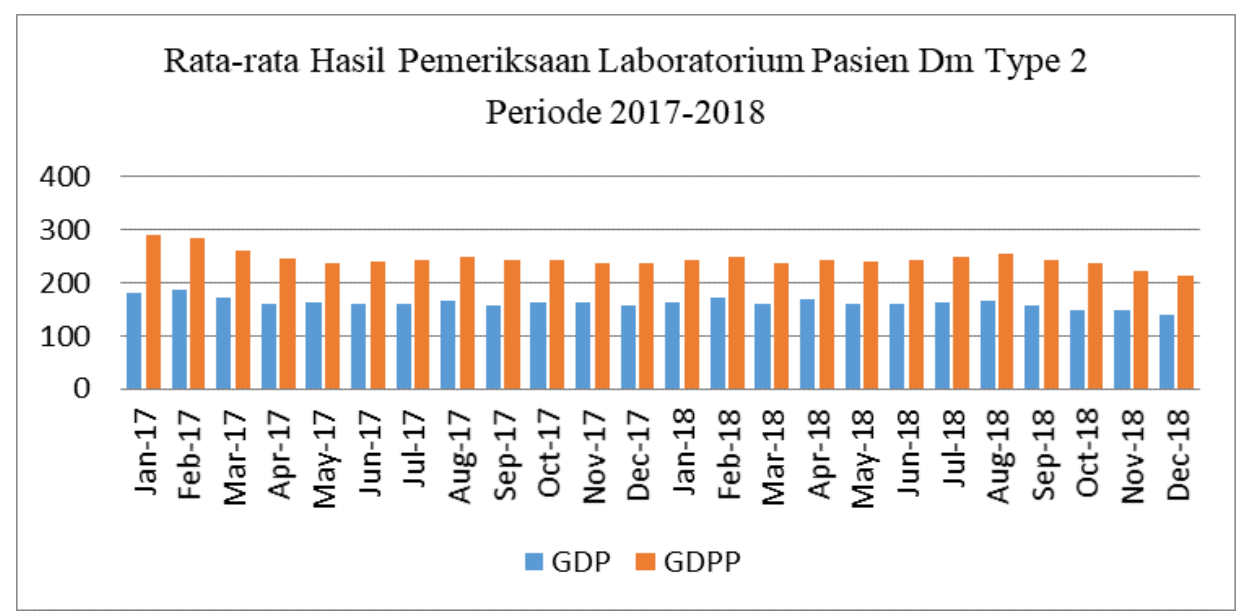

Gambar 1. Rata-rata hasil Laboratorium Pasien DM Type 2

Pengguna Insulin Periode 2017-2018

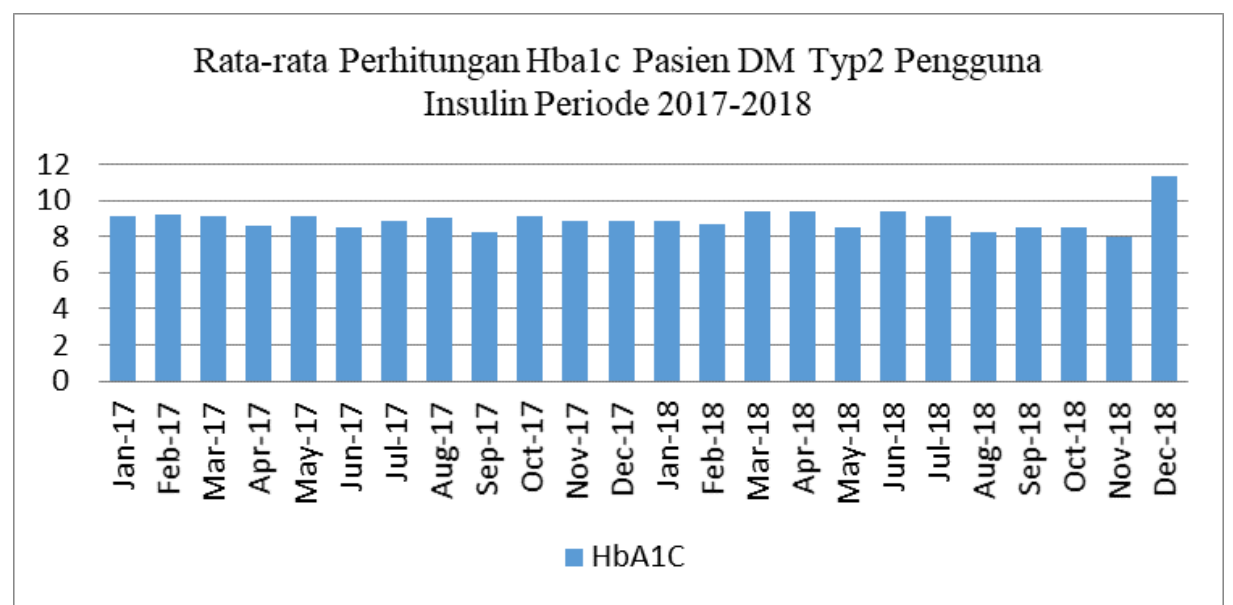

Gambar 2. Rata-rata hasil Perhitungan HbA1C Pasien DM Type 2 Pengguna Insulin Periode 2017-2018

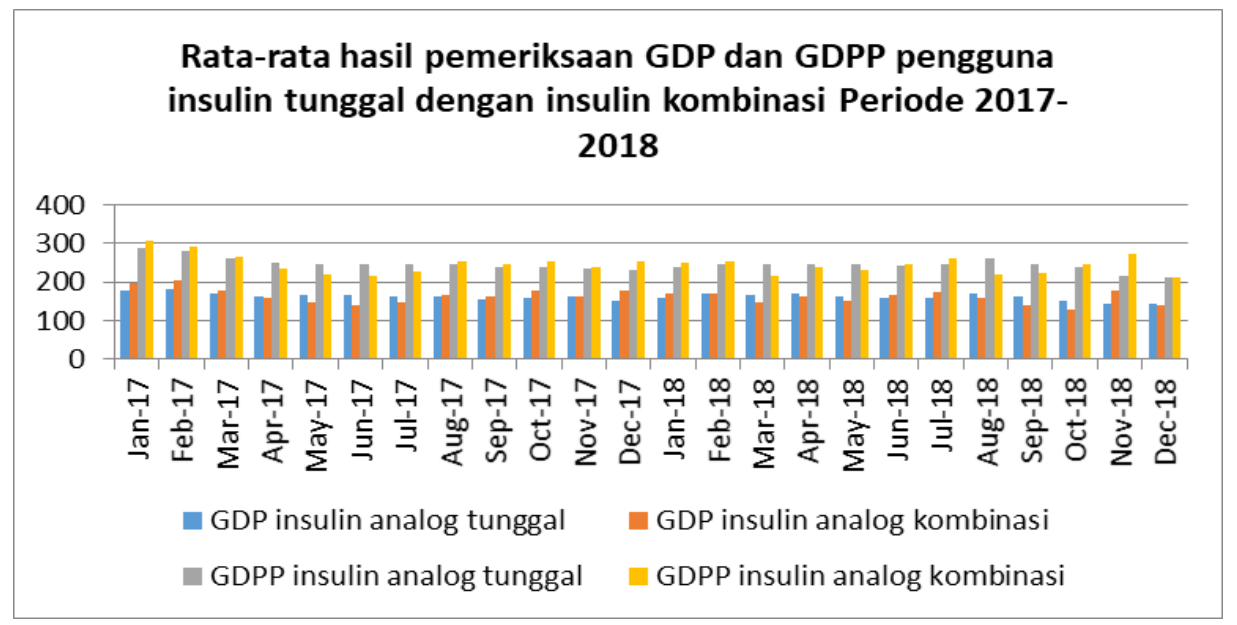

Gambar 3. Rata-rata hasil Laboratorium Pasien DM Type 2 Pengguna Insulin Tunggal dan Kombinasi Periode 2017-2018 


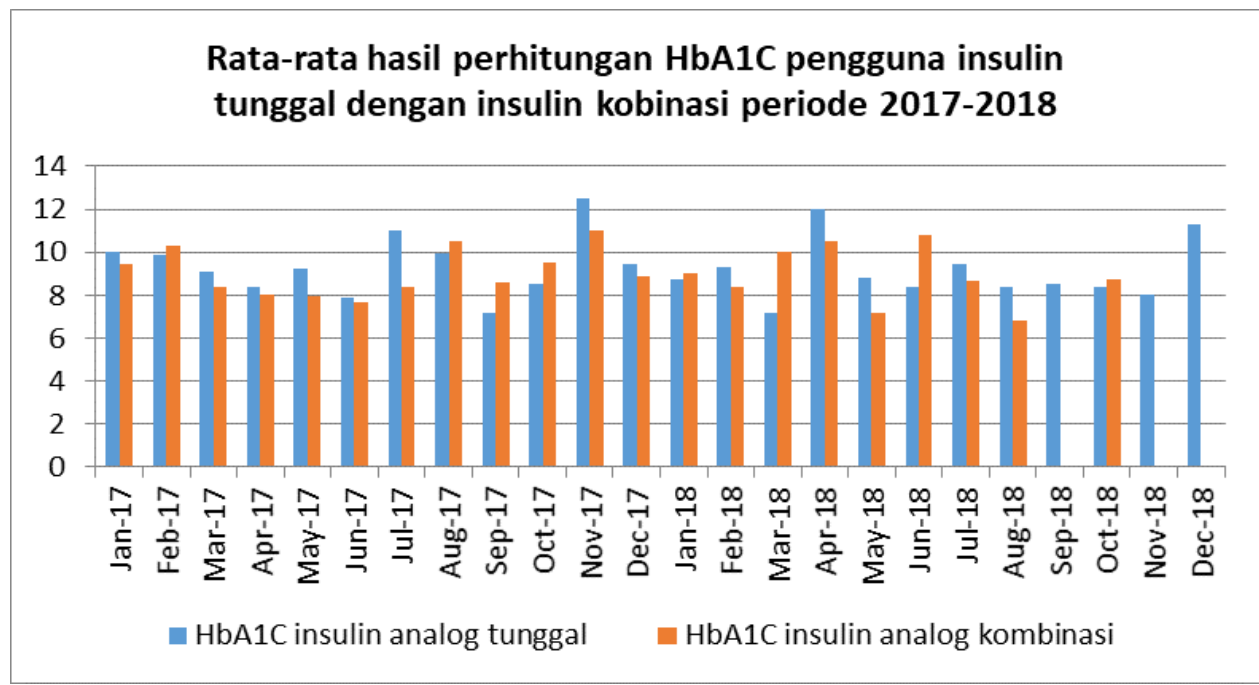

Gambar 4. Rata-rata hasil Perhitungan HbA1C Pasien DM Type 2 Pengguna Insulin Tunggal dan Kombinasi Periode 2017-2018

Berdasarkan gambar 3. hasil pemeriksaan laboratorium GDP dan GDPP berdasarkan jenis insulin diperoleh bahwa pada tahun 2017, rata-rata nilai GDP sebesar $165 \mathrm{mg} / \mathrm{dL}$ pada insulin analog tunggal dan $169 \mathrm{mg} / \mathrm{dL}$ pada insulin analog kombinasi. Rata-rata nilai GDP tertinggi pada insulin analog tunggal pada bulan Februari 2017 yaitu $183 \mathrm{mg} / \mathrm{dL}$ dan terendah pada bulan Desember 2017 yaitu $151 \mathrm{mg} / \mathrm{dL}$. Untuk jenis insulin analog kombinasi, rata-rata nilai GDP tertinggi pada bulan Februari 2017 sebesar $204 \mathrm{mg} / \mathrm{dL}$ dan terendah pada bulan Juni 2017 sebesar 139 mg/dL. Rata-rata Nilai GDPP tahun 2017 sebesar $250 \mathrm{mg} / \mathrm{dL}$ pada insulin analog tunggal dan $251 \mathrm{mg} / \mathrm{dL}$ pada insulin analog kombinasi. Rata-rata nilai GDPP tertinggi pada insulin analog tunggal pada bulan Januari 2017 yaitu $287 \mathrm{mg} / \mathrm{dL}$ dan terendah pada bulan Desember 2017 yaitu $230 \mathrm{mg} / \mathrm{dL}$. Untuk jenis insulin analog kombinasi, rata-rata nilai GDPP tertinggi pada bulan Januari 2017 sebesar $307 \mathrm{mg} / \mathrm{dL}$ dan terendah pada bulan Mei 2017 sebesar $218 \mathrm{mg} / \mathrm{dL}$.

Pada tahun 2018, rata-rata nilai GDP sebesar $160 \mathrm{mg} / \mathrm{dL}$ pada insulin analog tunggal dan $157 \mathrm{mg} / \mathrm{dL}$ pada insulin analog kombinasi. Rata-rata nilai GDP tertinggi pada insulin analog tunggal pada bulan Januari 2018 yaitu 172 mg/dL dan terendah pada bulan Desember 2018 yaitu $142 \mathrm{mg} / \mathrm{dL}$. Untuk jenis insulin analog kombinasi, rata-rata nilai GDP tertinggi pada bulan November 2018 sebesar $177 \mathrm{mg} / \mathrm{dL}$ dan terendah pada bulan Desember 2018 sebesar $139 \mathrm{mg} / \mathrm{dL}$. Rata-rata Nilai GDPP tahun 2018 sebesar $240 \mathrm{mg} / \mathrm{dL}$ pada insulin analog tunggal dan $239 \mathrm{mg} / \mathrm{dL}$ pada insulin analog kombinasi. Ratarata nilai GDPP tertinggi pada insulin analog tunggal pada bulan Agustus 2018 yaitu $263 \mathrm{mg} / \mathrm{dL}$ dan terendah pada bulan Desember 2018 yaitu 214 $\mathrm{mg} / \mathrm{dL}$. Untuk jenis insulin analog kombinasi, rata-rata nilai GDPP tertinggi pada bulan November 2018 sebesar $272 \mathrm{mg} / \mathrm{dL}$ dan terendah pada bulan Desember 2018 sebesar $212 \mathrm{mg} / \mathrm{dL}$ 
Berdasarkan gambar 4. hasil perhitungan HbA1C berdasarkan jenis insulin diperoleh bahwa pada tahun 2017, rata-rata nilai HbA1C sebesar 9,0 pada insulin analog tunggal dan 9,0 pada insulin analog kombinasi. Rata-rata nilai HbA1C tertinggi pada insulin analog tunggal pada bulan November 2017 yaitu 12,5 dan terendah pada bulan September 2017 yaitu 7,15. Untuk jenis insulin analog kombinasi, rata-rata nilai HbA1C tertinggi pada bulan November 2017 sebesar 11 dan terendah pada bulan Juni 2017 sebesar 7,7.

Pada tahun 2018, rata-rata nilai HbA1C sebesar 9,0 pada insulin analog tunggal dan 7,0 pada insulin analog kombinasi. Rata-rata nilai HbA1C tertinggi pada insulin analog tunggal pada bulan April 2018 yaitu 12,0 dan terendah pada bulan Maret 2018 yaitu 7,2. Untuk jenis insulin analog kombinasi, rata-rata nilai HbA1C tertinggi pada bulan Juni 2018 sebesar 10,77 dan terendah pada bulan Agustus 2018 sebesar 6,8.

3. Evaluasi Penggunaan Obat

a) Jumlah Obat

1) Jumlah rata-rata obat per pasien

Hasil penelitian tentang jumlah rata-rata item obat yang diterima pasien DM tipe 2 di poli rawat jalan RSUP Persahabatan pada tahun 20172018 didapat rata-rata obat yang diperoleh pasien DM tipe 2 paling banyak 9 obat untuk obat non DM. Untuk obat DM, jumlah rata-rata terbanyak 1 obat. Makin banyak obat yang diterima menunjukkan bahwa pasien DM type 2 memiliki penyakit penyerta. Hasil ini juga dapat ditafsirkan bahwa pasien DM Type 2 RSU Persahabatan sebagian besar mendapatkan terapi dengan insulin.

2) Jumlah Obat Berdasarkan Penyakit Penyerta

Perbandingan jumlah obat yang diterima pasien secara umum sama dengan jumlah penyakit penyerta yang diderita. Adapun rata-rata jumlah obat yang diterima berdasarkan jumlah penyakit penyerta disajikan pada gambar 5. Pada gambar 5. terlihat bahwa apabila pasien mengalami peningkatan penyakit penyerta, maka jumlah obat yang akan diterima oleh pasien menjadi lebih banyak. Pasien yang tidak memiliki penyakit penyerta menerima 4 item obat yang terdiri dari insulin analog 1 item dan obat non DM 3 item obat. 


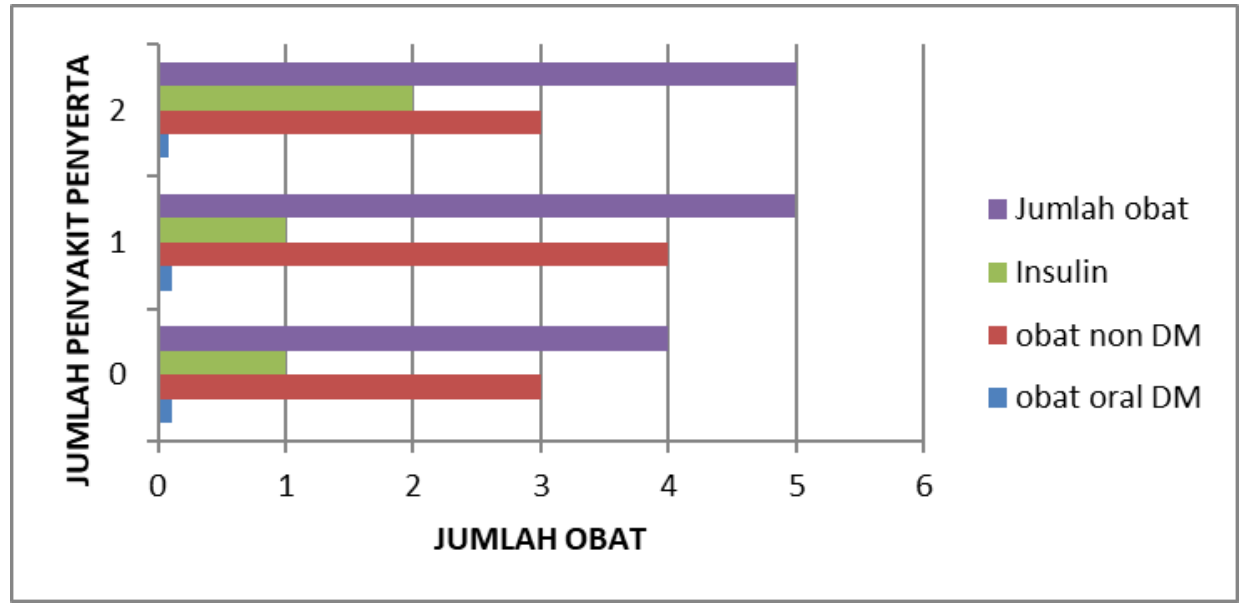

Gambar 5. Jumlah rata-rata item obat pasien DM tipe2 pengguna insulin berdasarkan penyakit penyerta

Pasien yang memiliki 1 penyakit penyerta menerima 5 item obat yang terdiri dari 1 item insulin dan 4 item obat non DM. Sedangkan pasien dengan 2 penyakit penyerta menerima 5 item obat yang terdiri dari 2 item insulin dan 3 item obat non DM. Komplikasi yang dialami mengakibatkan kerusakan jangka panjang termasuk disfungsi dan kegagalan berbagai organ tubuh, keterbatasan baik dari segi fisik, psikologis bahkan sosial, penyakit penyerta yang diderita antara lain TBC, Neuropati, gangguan sistem kardiovaskuler seperti hipertensi dan penyakit jantung (Wahyu Ningtyas D,dkk,2013).

Hasil ini sejalan dengan penelitian Vitriana G,dkk bahwa sebagian besar subyek pasien DM type 2 menderita komplikasi. Komplikasi yang terjadi pada sampel dibagi menjadi komplikasi mikroangiopati dan makroangiopati. Komplikasi mikroangiopati terbanyak adalah neuropati diabetik (37 orang, 20,9\%) dan komplikasi makroangiopati terbanyak adalah penyakit jantung koroner (51 orang, 28,8\%) (Ratnasari \& Bhargah, 2018).

3) Proporsi Obat DM dan Obat Non DM

Proporsi penggunaan obat DM maupun non DM dalam penelitian ini menunjukkan bahwa rata-rata peresepan untuk insulin $58,75 \%$, obat oral DM sebesar 5,53 \%, dan obat oral non DM sebesar 35,72\%. Dari data tersebut pasien DM tipe 2 rawat jalan mendapatkan terapi obat oral non DM lebih banyak dari obat oral DM. Hal ini berkaitan dengan penyakit penyerta ataupun komplikasi yang diderita oleh pasien tersebut. Obatobatan non DM yang paling sering diresepkan adalah obat-obat jantung, obat kolesterol, dan obat hipertensi sebagaimana disajikan tabel 2. dan Gambar 6.Hal ini sesuai dengan ADA 2010 dimana penyakit DM dapat mengakibatkan kegagalan organ tubuh seperti jantung, pembuluh darah, sistem saraf, ginjal (Melitus D.,dkk,2017). 
Tabel 2 Prosentase Jenis Obat Non DM yang digunakan pada pasien DM tipe 2 Pengguna Insulin tahun 2017- 2018

\begin{tabular}{lc}
\hline \multicolumn{1}{c}{ Jenis Obat } & Proporsi \\
\hline Anti fungi & $0,57 \%$ \\
\hline Anti koagulan & $0,68 \%$ \\
\hline Anti Parkinson & $0,68 \%$ \\
\hline Anxiolitik & $0,68 \%$ \\
\hline Tiroid & $0,90 \%$ \\
\hline Antihistamin & $2,71 \%$ \\
\hline Neurotropik & $2,71 \%$ \\
\hline Obat saluran pencernaan & $2,71 \%$ \\
\hline Urin alkali & $2,71 \%$ \\
\hline Antibiotik & $3,05 \%$ \\
\hline Obat TBC & $3,39 \%$ \\
\hline Gout & $4,30 \%$ \\
\hline Analgetik/antipiretik & $4,41 \%$ \\
\hline Obat pencernaan & $9,84 \%$ \\
\hline Vitamin & $9,95 \%$ \\
\hline Obat kolesterol & $11,20 \%$ \\
\hline Hipertensi & $16,06 \%$ \\
\hline Obat jantung & $23,42 \%$ \\
\hline
\end{tabular}

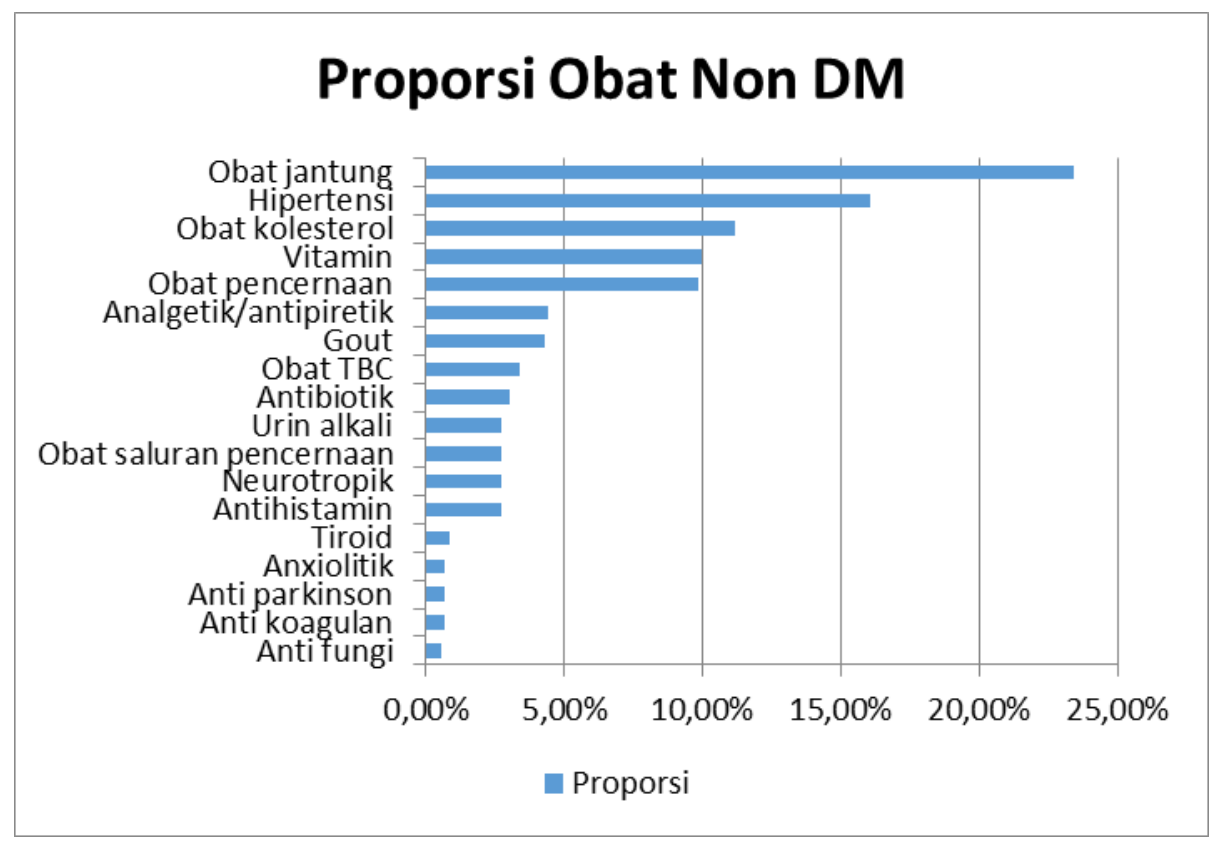

Gambar 6 Proporsi Jenis Obat non DM Pasien Type 2 yang Menggunakan insulin Periode 2017-2018

4) Golongan Obat Anti Diabetik Oral

Untuk terapi pengobatan pasien DM tipe 2 menurut Perkeni 2015 menyebutkan bahwa jenis obat anti diabetes oral yang digunakan adalah golongan glucosidase inhibitor, sulfonylurea, biguanid Prosentase jenis 
obat diabetes oral yang digunakan pada pasien DM tipe 2 tahun 2017-2018 dapat dilihat pada tabel 3. Dalam penelitian ini obat diabetes oral yang penggunaannya dikombinasi dengan insulin adalah golongan glucosidase inhibitor, sulfonilurea, dan biguanid.. Golongan obat yang paling banyak digunakan adalah Sulfonilurea yaitu sebesar 42,9\%.

Tabel 3 Prosentase obat Diabetes Oral yang digunakan pasien DM tipe 2 pengguna insulin tahun 2017-2018.

\begin{tabular}{lll}
\hline \multicolumn{1}{c}{ Golongan } & \multicolumn{1}{c}{ Nama Obat } & \multicolumn{1}{c}{ Prosentase } \\
\hline 1. Glucosidase inhibitor & Acarbose & $21,4 \%$ \\
\hline 2. Sulfonilurea & Glibenclamid & $3,6 \%$ \\
\hline & Glimepiride & $25,0 \%$ \\
\hline 3. Biguanid & Gliquidone & $14,3 \%$ \\
\hline
\end{tabular}

5) Proporsi penggunaan insulin

a) Peresepan insulin berdasarkan jenis insulin

Insulin yang digunakan sebagai terapi dalam penelitian ini hanya insulin analog, tidak ditemukan data insulin manusia sebagai terapi, dari tahun 2014 baik data di medical record maupun di instalasi farmasi. Penggunaan jenis insulin berdasarkan jenis insulin di RSUP Persahabatan dapat dilihat pada tabel 4 .

Tabel 4 Penggunaan jenis insulin di RSUP Persahabatan berdasarkan Jenis Insulin

\begin{tabular}{lcccccccc}
\hline \multirow{2}{*}{ Jenis Insulin } & \multicolumn{4}{c}{ Tahun 2017} & \multicolumn{3}{c}{ Tahun 2018} \\
\cline { 2 - 9 } & $\mathrm{N}$ & $\%$ & $\mathrm{~K}$ & $\%$ & $\mathrm{~N}$ & $\%$ & $\mathrm{~K}$ & $\%$ \\
\hline Apidra & 1 & $1 \%$ & 13 & $1 \%$ & 1 & $1 \%$ & 6 & $1 \%$ \\
\hline Humalog & 45 & $46 \%$ & 537 & $46 \%$ & 22 & $45 \%$ & 262 & $45 \%$ \\
\hline Lantus & 5 & $5 \%$ & 64 & $5 \%$ & 1 & $2 \%$ & 14 & $2 \%$ \\
\hline Levemir & 6 & $6 \%$ & 76 & $6 \%$ & 3 & $7 \%$ & 41 & $7 \%$ \\
\hline Novo rapid & 5 & $5 \%$ & 64 & $5 \%$ & 0 & $0 \%$ & 0 & $0 \%$ \\
\hline Novomix & 14 & $14 \%$ & 164 & $14 \%$ & 10 & $20 \%$ & 116 & $20 \%$ \\
\hline Humalog dan Lantus & 4 & $4 \%$ & 50 & $4 \%$ & 2 & $3 \%$ & 19 & $3 \%$ \\
\hline Humalog dan Levemir & 2 & $2 \%$ & 27 & $2 \%$ & 3 & $5 \%$ & 30 & $5 \%$ \\
\hline Humalog dan Novomix & 1 & $1 \%$ & 7 & $1 \%$ & 0 & $0 \%$ & 0 & $0 \%$ \\
\hline Lantus dan Apidra & 3 & $3 \%$ & 37 & $3 \%$ & 1 & $2 \%$ & 14 & $2 \%$ \\
\hline Lantus dan Novorapid & 5 & $5 \%$ & 59 & $5 \%$ & 3 & $5 \%$ & 30 & $5 \%$ \\
\hline Levemir dan Novorapid & 5 & $5 \%$ & 59 & $5 \%$ & 3 & $5 \%$ & 32 & $5 \%$ \\
\hline Novomix dan Lantus & 1 & $1 \%$ & 6 & $1 \%$ & 1 & $3 \%$ & 16 & $3 \%$ \\
\hline Novomix dan Levemir & 1 & $1 \%$ & 6 & $1 \%$ & 0 & $1 \%$ & 5 & $1 \%$ \\
\hline Humalog dan Glimepiride & 0 & $0 \%$ & 3 & $0 \%$ & 0 & $0 \%$ & 0 & $0 \%$ \\
\hline Novomix dan Acarbose & 0 & $0 \%$ & 5 & $0 \%$ & 0 & $0 \%$ & 0 & $0 \%$ \\
\hline
\end{tabular}


Berdasarkan tabel 4 menunjukkan bahwa jenis insulin yang sering digunakan pada pasien DM type 2 adalah insulin Humalog sebesar 46\% dari total pasien atau 46\% dari total kunjungan di tahun 2017 dan 45\% dari total pasien atau $45 \%$ dari total kunjungan pasien.

b) Peresepan jenis insulin berdasarkan trend merk

Peresepan insulin berdasarkan merk yang digunakan di RSUP Persahabatn pada tahun 2017 maupun tahun 2018 yang paling banyak digunakan adalah merk Humalog Mix yaitu pada tahun 2017 sebesar 45,62\% dan pada tahun 2018 44,79\%. Merk insulin ini merupakan insulin analog intermediate acting yang diproduksi oleh perusahaan di Indonesia, banyaknya jumlah pemakaian insulin ini karena lebih mudah dalam hal penggunaannya.

c) Peresepan jenis insulin berdasarkan lama kerja

Peresepan insulin berdasarkan lama kerja yang digunakan di RSUP Persahabatn dari tahun 2017 sampai tahun 2018, dapat dilihat pada tabel 6. Berdasarkan lama kerja insulin seperti yang disajikan tabel 6 terlihat bahwa insulin analoh intermediate acting adalah insulin yang paling banyak digunakan. Pada tahun 2017 sebanyak 59\% dari total pasien atau $61 \%$ dari total kunjungan dan pada tahun 2018 sebanyak $62 \%$ dari total pasien atau $62 \%$ dari total kunjungan.

\section{Outcome Klinik}

Tujuan dari pengobatan DM tipe 2 yaitu mencapai kendali glukosa yang baik, dalam hal ini kondisinya stabil sesuai dengan yang diharapkan. Parameter untuk menilai kestabilan penyakit DM dilakukan pemeriksaan GDP (gula darah puasa), GDPP (gula darah post prandial) dan HbA1C. Rata-rata hasil outcome klinik GDP untuk pasien usia $\leq 60$ tahun untuk yang terkendali baik adalah $8,3 \%$, untuk yang terkendali sedang adalah 13,6\%, dan yang tidak terkendali buruk 47,7\%. Untuk outcome klinik GDP pasien $>60$ tahun yang terkendali baik sebesar 3,6\%, untuk terkendali sedang sebesar 5,9\%, dan untuk tidak terkendali buruk sebesar 20,5\%. Untuk rata-rata outcome GDPP pasien usia $<60$ tahun untuk yang terkendali baik adalah $4,5 \%$, yang terkendali sedang sebesar $11,6 \%$, dan untuk yang tidak terkendali buruk sebesar 53,7\%. Untuk outcome klinik rata-rata pasien usia > 60 tahun yang terkendali baik sebesar $2,0 \%$, yang terkendali sedang sebesar $5,0 \%$, dan untuk yang tidak terkendali buruk sebesar 23,0\%.

Untuk rata-rata outcome $\mathrm{HbA1c}$, pasien usia $<60$ tahun untuk terkendali baik adalah $0,2 \%$, terkendali sedang $1,1 \%$, dan yang tidak terkendali buruk sebesar $11,2 \%$. Untuk outcome rata-rata pasien usia $>60$ tahun yang terkendali baik sebesar $0,1 \%$, terkendali sedang $0,5 \%$, dan untuk yang tidak terkendali buruk sebesar $4,8 \%$.

\section{Uji Beda Outcome Klinik}

Hasil perhitungan Uji beda outcome klinik menggunakan Uji Beda Kruskal Wallis menggunakan SPSS versi 23. Berdasarkan uji Kruskall Walls pada outcome GDP, nilai P value (Sig.) sebesar 0,05 (sig. $\leq 0,05$ ) artinya Ho ditolak sehingga dapat 
disimpulkan bahwa ada perbedaan yang signifikan diantara golongan insulin (minimal ada satu pasang golongan yang berbeda nyata) terhadap outcome GDP pasien DM type 2 di RSU Persahabatan. Berdasarkan analisis uji Kruskall Walls pada outcome GDPP diperoleh nilai P value (Sig.) sebesar 0.282 (Sig. >0.005) artinya Ho diterima sehingga dapat disimpulkan bahwa tidak ada perbedaan yang signifikan diantara golongan insulin. terhadap outcome GDPP pasien DM type 2 di RSU Persahabatan. Berdasarkan analisis uji Kruskall Wallis pada outcome HbA1c diperoleh nilai $\mathrm{P}$ value (Sig.) sebesar 0.672 (Sig. <0.005) artinya Ho diterima sehingga dapat disimpulkan bahwa tidak ada perbedaan yang signifikan diantara golongan insulin terhadap outcome HbA1c pasien DM type 2 di RSU Persahabatan.

Tabel 6 Penggunaan jenis insulin di RSUP Persahabatan berdasarkan Lama Kerja

\begin{tabular}{|c|c|c|c|c|c|c|c|c|c|}
\hline \multirow{2}{*}{$\begin{array}{c}\text { No } \\
\text {. }\end{array}$} & \multirow{2}{*}{ Golongan Insulin } & \multicolumn{4}{|c|}{ Tahun 2017} & \multicolumn{4}{|c|}{ Tahun 2018} \\
\hline & & $\mathbf{N}$ & $\%$ & $\mathbf{K}$ & $\%$ & $\mathbf{N}$ & $\%$ & $\mathbf{K}$ & $\%$ \\
\hline \multirow[t]{4}{*}{1.} & Insulin Analog & & & & & & & & \\
\hline & $\begin{array}{l}\text { a. Insulin analog fast } \\
\text { acting }\end{array}$ & 13 & $6 \%$ & 59 & $5 \%$ & 2 & $2 \%$ & 3 & $1 \%$ \\
\hline & $\begin{array}{l}\text { b. Insulin analog } \\
\text { intermediate acting }\end{array}$ & $\begin{array}{c}12 \\
7\end{array}$ & $59 \%$ & 723 & $\begin{array}{l}61 \\
\%\end{array}$ & 80 & $62 \%$ & $\begin{array}{c}36 \\
2\end{array}$ & $\begin{array}{l}62 \\
\%\end{array}$ \\
\hline & $\begin{array}{l}\text { c. Insulin analog long } \\
\text { acting }\end{array}$ & 15 & $7 \%$ & 68 & $6 \%$ & 11 & $8 \%$ & 47 & $8 \%$ \\
\hline \multirow[t]{6}{*}{2.} & $\begin{array}{c}\begin{array}{c}\text { Kombinasi Insulin } \\
\text { analog }\end{array} \\
\end{array}$ & & & & & & & & \\
\hline & $\begin{array}{l}\text { a. Kombinasi Insulin } \\
\text { analog intermediate } \\
\text { acting dan ADO }\end{array}$ & 7 & $3 \%$ & 35 & $3 \%$ & 3 & $2 \%$ & 20 & $3 \%$ \\
\hline & $\begin{array}{l}\text { b. Kombinasi Insulin } \\
\text { analog long acting dan } \\
\text { ADO }\end{array}$ & 6 & $3 \%$ & 39 & $3 \%$ & 2 & $2 \%$ & 7 & $1 \%$ \\
\hline & $\begin{array}{l}\text { c. Kombinasi insulin } \\
\text { analog long acting dan } \\
\text { fast acting }\end{array}$ & 28 & $13 \%$ & 160 & $\begin{array}{l}14 \\
\%\end{array}$ & 17 & $13 \%$ & 78 & $\begin{array}{l}13 \\
\%\end{array}$ \\
\hline & $\begin{array}{l}\text { d. kombinasi insulin } \\
\text { analog long acting dan } \\
\text { intermediate acting }\end{array}$ & 16 & $7 \%$ & 86 & $7 \%$ & 15 & $12 \%$ & 69 & $\begin{array}{l}12 \\
\%\end{array}$ \\
\hline & $\begin{array}{l}\text { e. Kombinasi insulin } \\
\text { analog long acting, fast } \\
\text { acting dan ADO }\end{array}$ & 2 & $1 \%$ & 7 & $1 \%$ & 0 & $0 \%$ & 0 & $0 \%$ \\
\hline
\end{tabular}

Uji Mann Whitney adalah uji lanjut dari Uji Kruskaal Wallis. Berdasarkan hasil uji Mann Whitney, dengan 28 kelompok pasangan insulin, diperoleh hasil nilai outcome klinik GDP berbeda nyata yaitu pada perbandingan terapi antara insulin fast acting dengan insulin analog intermediate acting, begitupun antara insulin fast acting 
dan kombinasi insulin, baik kombinasi yang menggunakan 2 macam insulin analog, maupun kombinasi antara insulin analog dan ADO. Pada uji nilai outcome klinik GDPP berbeda nyata pada perbandingan terapi antara insulin fast acting maupun insulin long acting dengan kombinasi insulin intermediate acting dan ADO. Pada hasil $\mathrm{HbA1c}$ menunjukkan tidak ada perbedaan penggunaan terapi berbagai jenis insulin.

\section{Kesimpulan}

Obat DM oral yang banyak diresepkan adalah Sulfonilurea sebesar 42,9\%. Obat non DM yang sering diresepkan adalah obat jantung (23,42\%). Insulin yang sering digunakan berdasarkan jenis adalah insulin Humalog, berdasarkan merk adalah Humalog Mix dan berdasarkan lama kerja adalah Insulin analog intermediate acting. Berdasarkan outcome klinik, outcome klinik GDP, GDPP dan HbA1C pada pasien usia $\leq 60$ tahun atau > 60 tahun secara umum termasuk tidak terkendali/buruk. Ada perbedaan yang signifikan diantara golongan insulin (minimal ada satu pasang golongan yang berbeda nyata) terhadap outcome GDP. Namun tidak ada perbedaan yang signifikan diantara golongan insulin terhadap outcome GDPP dan HbA1C. Berdasarkan hasil uji Mann Whitney, dengan 28 kelompok pasangan insulin, diperoleh hasil nilai outcome klinik GDP berbeda nyata yaitu pada perbandingan terapi antara insulin fast acting dengan insulin analog intermediate acting, begitupun antara insulin fast acting dan kombinasi insulin, baik kombinasi yang menggunakan 2 macam insulin analog, maupun kombinasi antara insulin analog dan ADO. Pada uji nilai outcome klinik GDPP berbeda nyata pada perbandingan terapi antara insulin fast acting maupun insulin long acting dengan kombinasi insulin intermediate acting dan ADO. Pada hasil HbA1c menunjukkan tidak ada perbedaan penggunaan terapi berbagai jenis insulin. 
Evaluasi Profil Pengobatan dan Outcome Klinis Penggunaan Insulin Analog

\section{BIBLIOGRAFI}

Andayani, Tri Murti. (2006). Analisis biaya terapi Diabetes mellitus Rumah Sakit Dr . Sardjito Yogyakarta. Majalah Farmasi Indonesia, 17(3), 130-135.

Badan Penelitian dan Pengembangan Kesehatan Kementerian Kesehatan RI. (2013). Riset Kesehatan Dasar.

Baroroh, Faridah, Solikah, Wahyu Yuliana, \& Urfiyya, Qarriy Aina. (2016). Analisis biaya terapi Diabetes Melitus tipe 2 Di Rumah Sakit Pku Muhammadiyah Bantul Yogyakarta. Jurnal Farmasi Sains Dan Praktis, I(2), 11-22.

Cai Le, Dong Jun, Shuzhankun, Lu Yichun and Tao Jie. (2011). Socioeconomic Difference In Diabetes Prevalence, Awarness, and Treatment in Rurel Southwest China. Tropical Medicine and International Health, 16.

Direktur Utama BPJS Kesehatan. (n.d.). Panduan Praktis Program Rujuk Balik Bagi Peserta JKN.

Eliza B Geer, Wei Shen. (2010). Gender Differences in insulin Resistance, Body Composition and Energy, Supplemen 1. NIH.

Emma,Wilmot \& Idris, Iskandar. (2014). Early Onset Type 2 Diabetes: Risk Factor, Clinical Impact, and Management. Therapeutic Advance in Chronic Disease, 234244.

FDA. (2013). Clinical Outcome Assesment Qualification Program.

Frank, HU. (2008). Nutrisi \& Epidemiologi. Harvard School of Public Health.

IDF clinical practice recommendations for managing type 2 diabetes in primary care. (2017). In International Diabetes Federation (Vol. 132).

Kementerian Kesehatan Badan Penelitian dan pengembangan Kesehatan. (2018). Hasil Utama Laporan Riskesdas 2018.

Kistianita, Ayu Nindhi, \& Gayatri, Rara Warih. (2018). Analisis Faktor Risiko Diabetes Mellitus Tipe 2 Pada Usia Produktif Dengan Pendekatan Who Stepwise Step 1 (Core / Inti) di Puskesmas Kendalkerep Kota Malang. Preventia: The Indonesian J of Public Health, 3(1), 1-14.

Melitus, Diabetes, Di, Tipe, Wahidin, Rsup, \& Oryza, Rori. (2017). Sudirohusodo Makassar Profile of Antihypertension Treatment in Diabetes Melitus Type 2 Patients At Rsup Dr . Wahidin Sudirohusodo Makassar .

Ndraha, Suzanna. (2014). Diabetes Melitus Tipe 2 Dan Tatalaksana Terkini. Jurnal Keperawatan Klinis, 27(2), 1-8. 
Rosdaniati, Yusi Anggriani, Hesty Utami R. dan Tri Kusumaeni

Noor, N. .. (2008). Epidemiologi Konsep Penyebab Penyakit dan Hubungan Asosiasi.

Perkumpuan Endrokinologi Indonesia. (2015). Pengelolaan dan pencegahan Diabetes Melitus tipe 2 di Indonesia.

Ratnasari, Ni Luh Made Novi, \& Bhargah, Agha. (2018). Pola penggunaan insulin pada pasien diabetes mellitus tipe 2 di poli penyakit dalam RSU Negara Periode Juli-Agustus 2018.

Rosdiana, Dani. (2014). Penggunaan insulin basal dalam praktek sehari-hari : Panduan praktis untuk dokter Umum. JIK, 2, 53-57.

Sari, Firni Dwi, Inayah, Inayah, \& Hamidy, Muhammad Yulis. (2016). Pola penggunaan obat anti hiperglikemik oral pada pasien diabetes melitus tipe 2 rawat inap di Rumah Sakit X Pekanbaru tahun 2014. Riau University.

Srikart, Ika, Valentina Meta, Cahya, Annisa Dwi, Suci, Ratna, Hardiati, Wahyu, \& Srikartika, Valentina Meta. (2015). Analisis Faktor Yang Memengaruhi Kepatuhan Penggunaan Obat Pasien Diabetes Melitus Tipe 2 the Analysis of the Factors Affecting Medication Adherence in Patients. Jurnal Manajemen Dan Pelayanan Farmasi, 206 Volume(2011), 205-212.

Stanifer, J.W., Cleland, C.R., Makuka, G.J.,Egger, R., Maro, V., Maro, H., Barengo, C. (2016). Prevalence, risk factors, and complications of diabetes in the Kilimanjaro Region. 1-13.

Tri Hastuti, Rini. (2008). Faktor-faktor Risiko Ulkus Diabetika Pada Penderita Diabetes Mellitus (Studi Kasus di RSUD Dr. Moewardi Surakarta). Program Pasca Sarjana Universitas Diponegoro.

Wahyu Ningtyas, Dwi, Pudjo Wahyudi, Dr, Prasetyowati, Irma, Fakultas Kesehatan Masyarakat, MKes, \& Jember Jln Kalimantan, Universitas I. (2013). Analisis Kualitas Hidup Pasien Diabetes Melitus Tipe II di RSUD Bangil.

Widodo, Cahyono, Tamtomo, Didik, \& Prabandari, Ari Natalia. (2016). Hubungan aktifitas fisik, kepatuhan mengkonsumsi obat anti diabetik dengan kadar gula darah pasien Diabetes Mellitus di Fasyankes primer Klaten. Jurnal Sistem Kesehatan, 2(36), 63-69. 